\title{
Urban Landscape Evolution as a Consequence of an Invasive Pest: The Case of a Small Sicilian Town
}

\author{
Emanuele Schimmenti, Valeria Borsellino ${ }^{*}$, Giuseppe Ingrassia2, Ezio Peri1, \\ Vittorio Farina, Salvatore Guarino 1 \\ 1 Università degli Studi di Palermo, Dipartimento di Scienze Agrarie, Alimentari e Forestali, Viale delle Scienze, Ed. 4, 90128 \\ Palermo (PA), Italy \\ 2 C/da Calarco 4 - 98076 Sant'Agata di Militello (Me) Italy
}

\begin{abstract}
The Red Palm Weevil (RPW), after its accidental introduction in Italy in 2005, determined a progressive disruption of Canary palms mostly in the central and southern regions. As it is difficult to undertake the management of this pest, the possibility of substituting the killed/symptomatic palms with other ornamental trees has been recently discussed. In this context, understanding the citizens' needs about green areas can improve the management of public parks and urban greening. Involving citizens on the natural resource management using public participation processes is crucial. The case study of a small town of Sicily (Italy) was treated and the spread of this pest was monitored. Moreover, the possibility of substituting the killed palms with other ornamentals was discussed by involving a sample of the population through a direct survey aimed at detecting the preferences in respect to certain tree species (as potential substitutes of the killed palms) listed in a questionnaire administered face-to-face. The citizen's samples showed great interest in the green areas (97\%) and indicated a traditional Mediterranean plant as Nerium oleander as the preferred palm substitute candidate.
\end{abstract}

\section{Keywords:}

Citizens' perceptions; Urban landscape; Palms; Red Palm Weevil.

\footnotetext{
*Corresponding author. Email: valeria.borsellino@unipa.it

(C) The Authors. 2017. Landscape Online. This is an Open Access article distributed under the terms of the Creative Commons Attribution License (http://creativecommons.org/licenses/by/4.0), which permits unrestricted use, distribution, and reproduction in any medium, provided the original work is properly cited.
} 


\section{Introduction}

\subsection{The impact of invasive pests on landscapes}

Alien insects are increasingly being dispersed around the world through international trade causing a multitude of negative impacts on ecosystems, agriculture, forestry, and landscapes, with consequences on human health in addition to annual economic losses of billions of dollars (Bacon et al. 2012).

The main share of these alien insects is confined to man-made habitats (Roques et al. 2009). Human habitats may be more readily invaded by insects than natural habitats because insects linked to human environments and activities are more likely to be carried by human transport into a new region than insects living in natural areas (Kenis et al. 2009). On the other hand, the green urban areas are of crucial importance in towns not only for their ornamental and recreational role, but also for their effect on local temperature reduction (Takebayashi, Moriyama 2007). Therefore, the augmentation of urban vegetation as a possible mitigation strategy for the so called 'urban heat islands' is recommendable (Susca et al. 2011). Furthermore, the extreme simplified structure of urban ecosystems makes these habitats particularly susceptible to the invasive species.

Italy is particularly vulnerable to the ingress of alien insects due to its geographical position as it is a nodal point for commerce and tourism in the centre of the Mediterranean basin. Furthermore, the range of Italian climatic parameters allows the establishment of subtropical species in the southern regions (Pellizzari et al. 2005). These facts expose Italy to greater risks of having alien species dangerous not only for agroecosystems and forestry but also for the ornamentals of green spaces of urban areas. In particular, herbivore outbreaks in urban environments have been linked to improved host quality resulting from environmental stress associated with impervious surfaces and elevated temperatures as well as fleeing from natural enemies (Raupp et al. 2010). A recent example of such outbreaks is the invasion of the Red Palm
Weevil (RPW) Rhynchophorus ferrugineus Olivier that, after its accidental introduction in 2005 (Longo, Tamburino 2005), determined, over the years, a progressive impact on the Italian green landscape areas (Ferry, Gomez 2002; Kontodimas et al. 2006; European Commission 2011; Pasini, Rumine 2014). In 2007, the Italian Ministry of Agriculture, Food and Forestry, in order to contrast the widespread of the RPW, decreed a series of guidelines for the mandatory control of this pest (Ministerial decree, 9/11/2007). Later, the Regional Phytosanitary Services of the most affected regions started to adopt regional decrees (RDs) for the control of the RPW (e.g. Campania RD 31/1/2006 and 18/1/2008; Sicily RD 23/3/2007; Latium RD 5/6/2007). These RDs provided for management measures to be taken in infested areas, which included penalties for non-compliance. From the actuation of these directives in infested areas, all citizens who found a new RPW-infested palm had to alert the Regional Plant Protection Services to assess the most suitable phytosanitary measures and inform the relevant municipal administration. These measures permitted the recognition of around 20,000 RPW-infested palms in Sicily in the period 2006-2011, of which 16,000 were cut and destroyed (Raciti et al. 2013). However, these control procedures were hindered by several factors such as the lack of adequate funding, structures and number of skilled people for the destruction of the infested palms and so the pest continued to expand through the country.

\subsection{The spread of RPW}

The RPW attacks mainly Phoenix canariensis Hort. ex Chabaud, the Canary island palm (Longo et al. 2011). In Sicily observations conducted from 2007 to 2010 revealed that $99.7 \%$ of the RPW-infested palms belonged to the $P$. canariensisspecies while the remaining $0.3 \%$ belonged to other palm species, such as Phoenix dactylifera L., Washingtonia spp. and Chamaerops humilis L. (Peri et al. 2013).

P. canariensis is mainly used for ornamental purposes in Sicily (Noto, Romano 1987), and it is the most widespread palm species planted in historical gardens (Raciti et al. 2013) and consequently the RPW became a serious pest of the monumental, 
urban and country landscape. The historical study carried out by Raciti et al. (2013) showed that $P$. canariensis plants were reduced because of the RPW invasion by $90 \%$ between 2006 and 2012 on the eastern coast of Sicily.

The impact of RPW on landscape had strong economic consequences both for the public administration due to the management of the dead plants, as these had to be removed, destroyed and sometimes substituted, and of the nurseries, an importante conomic activity within the Sicilian region, where nearly $50 \%$ of the national production of ornamental palms is concentrated (Giovino et al. 2009). The nurseries, in fact, have suffered a drastic reduction on the palm commerce and consequently high operating costs due to storage: Giovino et al. (2009) estimated damages of nearly 12 million euros in the period 2005-2008.

\subsection{The rehabilitation of urban green spaces}

The RPW invasion posed questions on the problem of rehabilitation of urban green spaces and landscape contexts, in which the palms were one of the most distinctive features in the past, specifically if considering that their substitution appears difficult from an aesthetic, functional and economic point of view (Manachini et al. 2013; Raciti et al. 2013). It is also important to take into account that when the public decision-maker is planning to carry out choices about preservation, creation and management of urban green areas, which often require large-scale capital investments, the support of professional skills in biological sciences is not enough for him, but it is often necessary to assess socio-economic aspects and to identify the social welfare resulting from such interventions (Marone, Riccioli 2008; Dempsey, Burton 2012; Gomez-Baggethun, Barton 2013). Furthermore, the involvement of citizens in public decision-making to meet community expectations on green areas preferences can contribute to generate better decisions for the municipal administration in properly allocating the scarce public financial resources available (Marone, Riccioli 2008; Lanfranchi et al. 2015; Giannetto et al. 2016). However, today the rehabilitation and/or improvement of urban green spaces is underestimated and/or not effectively faced by the public decision-maker, who merely implements mostly routine maintenance interventions of green areas (Lorenzo et al. 2000). In the meantime, citizens are making greater demands for a more active role in the planning and decisions about the management of green spaces in their communities (Roseland 1998; Simonsen, Robbins 2000; Sanesi, Chiarello 2006; Chan et al. 2012; Martin-Lopez et al. 2012). It is essential for urban planners and policy makers to understand these factors as better urban greening participation processes are seen as crucial provisions to better functioning and valued urban spaces (Konijnendijk 2000; Simonsen, Robbins 2000; Trakolis 2001; Van Herzele et al. 2005, Jim, Chen 2006; Buchel, Frantzeskaki 2015). Moreover, possible solutions to problems that threaten the ecosystem require the expertise of biologists and, at the same time, their complexity demands integrated efforts involving other disciplines such as sociology, and economics (Palmer et al. 2005; Eigenbrode et al. 2007; Manachini et al. 2013).

\subsection{Goals of the study}

In this research, realized with an interdisciplinary approach, the case-study of the green public areas of the town of Sant'Agata di Militello (Sicily, Italy) was examined. This town on the northern coast of Sicily, presents maximum temperatures generally above 27 degrees Celsius from June to September. Consequently, in such an environment the importance of mitigating green spaces the summer heat is particularly important.

During the last 50 years, $P$. canariensis trees, which were recently destroyed by the RPW invasion, were mainly used in public gardens and tree-lined streets in the city centre and alongside the seaside promenade.

This study focuses on the environmental and historical value of palms in urban areas, the effect of the RPW in determining changes in urban landscape, the perception and interest of the citizens for the green areas and the relative problem of substituting the killed palms. 


\section{Palms in urban areas}

$\mathrm{M}$ odern cities are planned with a variety of green spaces including parks, small home gardens and tree-lined streets. We can identify different kinds of urban ecosystems manipulated and managed by man such as street trees, lawns/parks and urban forests (Bolund, Hunhammar 1999). All of these green spaces constitute biodiversity hotspots (Jim, Chen 2009; Goddard et al. 2010) and also provide crucial habitats for urban flora and fauna (Freestone, Nichols 2004; Khera et al. 2009). They are planned for several purposes providing recreational, social and psychological functions, helping to clean air (gas regulation), to limit noise levels, to control rainwater drainage and to buffer microclimatic variations (Chiesura 2004). Trees reduce air pollution (Islam et al. 2012) and the filtering capacity increases with more leaf area. The positive actions on the environment depend not only on the characteristics of the green areas but also chiefly by the tree species. Urban vegetation, generally, exhibits a great heterogeneity of species and it is characterized by a high level of diversity with a large proportion of exotic species (Khera et al. 2009).

The presence of palms in historical and traditional gardens located in Sicily has been observed by many authors (Pavone, Salmeri 1994; Salmeri et al. 2007; Barbera, Romano 2009). Palm trees play a key role in the Mediterranean landscapes with numerous species of ancient introduction. The high rusticity and longevity, the non-invasive roots and the canopy characteristics justify their wide dissemination in both public and private gardens. Some palm trees are planted in areas near the sea, where the vegetation is exposed to the mechanical action of the wind and sand, abrasive salt, and sometimes to the same spray of sea water. Moreover, palm trees can even live in soils, which do not have the optimal physicochemical characteristics as the urban ones (Noto, Romano 1987). Among the widespread species in Sicilian gardens, $P$. canariensis is the most observed ( $87 \%$ of gardens reviewed), followed by C. humilis (56\%), Washingtonia filifera (Lindl.) $\mathrm{H}$. Wendl. (49\%), Washingtonia robusta (Lindl.) H.
Wendl. (48\%) and P. dactylifera (39\%) (Raciti et al. 2013). Furthermore, several palms belonging to the Phoenix genus have particular relevance in Sicily for their ornamental role in the surroundings of ancient churches, monuments and other places of high historical value (Barbera, Romano 2009).

\section{The impact of the invasive species in urban landscapes, a model study in the town of Sant'Agata di Militello}

Cant'Agata di Militello is a small town (almost $S_{12,000}$ inhabitants) located on the north coast of Sicily where palms, mainly the species $P$. canariensis and marginally $C$. humilis, and Washingtonia spp., have been widely used as ornamentals in streets and gardens. The latter counted around 300 trees before the arrival of the invasive RPW. The first Canary palm infested by the RPW in this town was observed in September 2012, almost seven years after the introduction of the RPW in Sicily. Since then, the number of infested Canary palms has rapidly increased.

In this contest a monitoring study was carried out to assess the increase in the number of palms killed and symptomatic in the period 23/11/2013 - 10/5/2014. The total number of Canary palms monitored was 165.

The palms were visually inspected at the beginning and at the end of the study and categorized into:

- Symptomatic palms, i.e. plants with a loss of symmetry of the leaves and tendency of the canopy to flatten (Figure $1 \mathrm{~A}-\mathrm{B}$ );

- Killed palms, i.e. plants with all the leaves dried and hanging downward in a typical 'umbrella shape' (Figure $1 \mathrm{C}$ );

- Healthy plants, i.e. plants not showing any visual symptoms.

The position of each palm was recorded using a GPS system. 


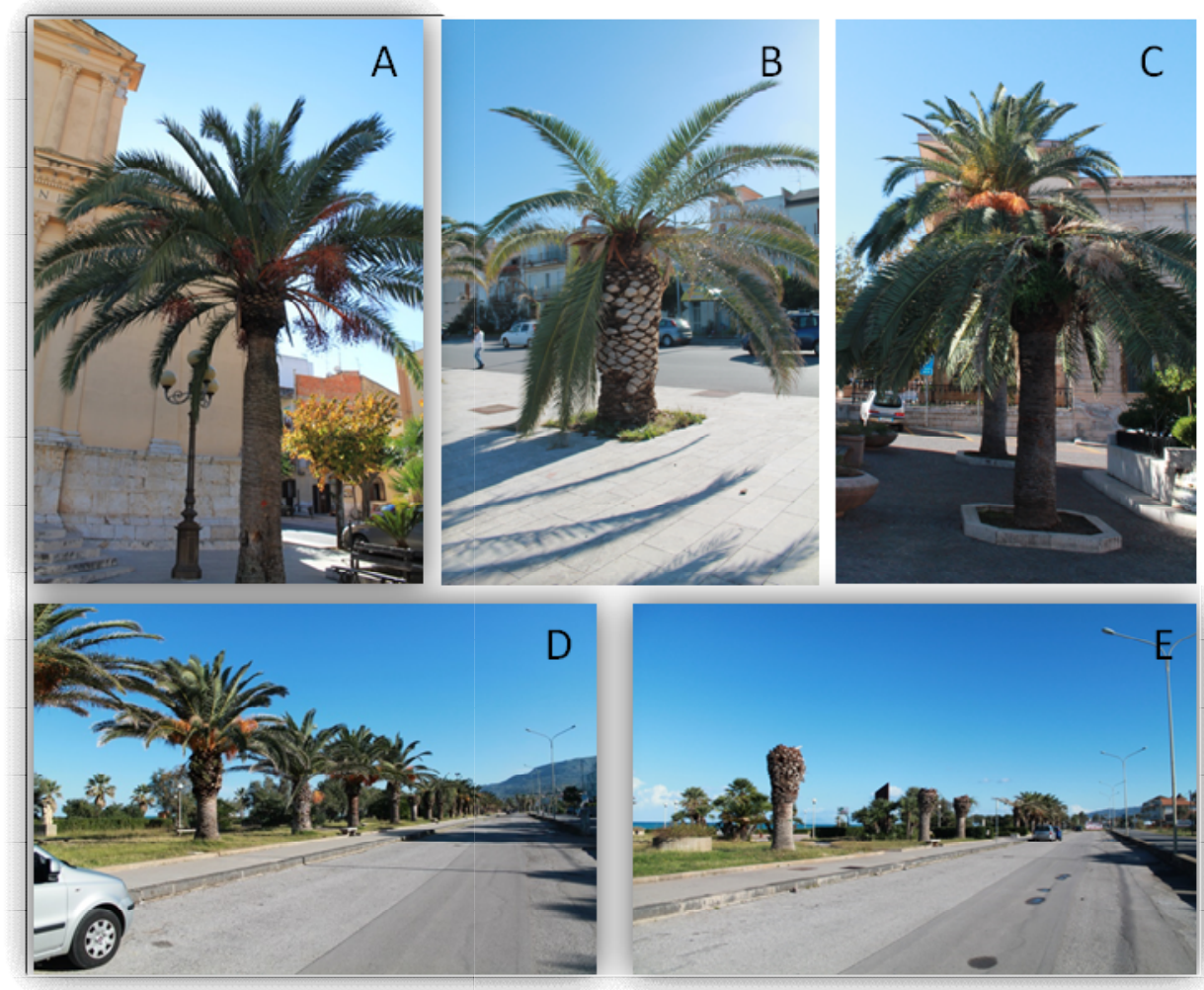

Figure $1(A-E)$ : Phoenix canariensis at different levels of infestation: $(A)$ early symptoms; (B) symptomatic palm with loss of symmetry of the leaves of the canopy; (C) late symptoms on a plant with the leaves dried and hanging downward in a typical 'umbrella shape'; Sant'Agata di Militello main road at the beginning (D) and at the end (E) of the monitoring period of the study.

At the start date, $23^{\text {rd }}$ November 2013 , the number of killed and symptomatic palms was respectively $42 \%$ and $14 \%$ of the total number of trees monitored.

However, at the end of the sampling period, $10^{\text {th }}$ May 2014, the number of killed and symptomatic palms increased respectively to $46 \%$ and to $27 \%$ of the total number of trees monitored (Figure $1 \mathrm{D}-\mathrm{E}$ ).

The decrease of the percentage of healthy palms during this period is particularly severe as it comprised all the winter season, in which new palm infestations unlikely occur as it is generally considered a non-flying period of the RPW. Therefore, it is conceivable that the infestations probably occurred in March-April, in correspondence to the RPW adult emergence. The increase of killed and/or symptomatic palms in this period might also have been determined by the lack of proper sanitation and eradication activities during the winter of 2013-2014; indeed, these measures, treating symptomatic plants and removing and destroying the killed ones, could help in reducing the RPW population and preventing further attacks (Faleiro 2006). The killed palms in the urban gardens of the town also concerned the potential danger of falling trees. Unfortunately, in some cases, the attempt of eradication of infested palms was carried out by private companies which were not adequately prepared and were without entomological skills. The correct application of eradication measures to manage invasive species of the urban green is quite difficult as they are expensive and because citizens, municipalities, nurseries, and other involved stakeholders frequently oppose the destruction of infested palm trees due to their landscape, cultural, tourism-related, and economic value (Nardi et al. 2011). Moreover, RPW populations showed tendency to rebuild rapidly even after significant control efforts as observed for example in other invasive species such as Cameraria ohridella, a leafmining moth, which determines aesthetic damage to horse chestnut trees (Gilbert et al. 2005). 


\section{The perceptions of green areas and the citizens' proposals}

\subsection{General aspects and survey design}

Local, as well as regional and national, authorities are significant and often the central players in urban forestry and greening (Lawrence et al. 2013). However, successful urban green space planning processes cannot dismiss citizen participation to avoid a failure of social and environmental functions that form a context for economic activities (Balram, Dragićević 2005). In this context, municipal planners, designers, and researchers are starting to recognize this need (Kühn 2003; Chiesura 2004; Frischenbruder, Pellegrino 2006; Janse, Konijnendijk 2007; Greene et al. 2011).

In the case of the town of Sant'Agata di Militello, during the last 50 years, the municipality has planned several gardens and boulevards in the town centre and alongside the sea promenade using numerous botanical ornamental species in order to favour the changing needs of the community on public green areas and to improve the tourism potential of the town. Among the ornamentals chosen in this specific context, $P$. canariensis has had a primary role, being used alongside the sea promenade and in the main public gardens.

After the RPW invasion and the consequent palm destruction, an intense debate among the citizens took place about the substitution of the destroyed plants of $P$. canariensis. The aim of this sociological study was to explore the perception and interest of the citizens for urban greening and directly involve them in the choice of ornamental plants for substitution of the killed palms. The explorative pilot survey proposed to the citizens was designed with the aim to detect their preferences on some tree species suitable for a possible replacement of $P$. canariensis specimens destroyed by the RPW. In addition to the major socio-demographic indicators of the respondents and their opinions on the interest on the management and maintenance conditions of public parks of their town. On the basis of other research studies carried out in the sector of perception of green spaces (Lorenzo et al. 2000; Asciuto et al. 2004a; Jim, Chen 2006; Sanesi, Chiarello 2006; Asciuto et al. 2015; Lee, Kim 2015), a questionnaire was specifically drawn up and divided into 3 parts. In the first part the main social and demographic indicators of the citizens interviewed were reported (gender, age, education and occupation); in the second part, questions were asked in order to assess the citizens interest about their fruition, the management and upkeep of the public green areas of Sant'Agata di Militello; in the third part, the survey investigated the preferences of the respondents between three plant species indicated in the questionnaire -Nerium oleander $L$., Tamarix gallica $L$. and $W$. filifera- as possible substitutes of the killed palms. The three ornamental plant species were selected considering both their adaptability to the climatic conditions of the area and their tolerance to phytophagous insect species or pathogens.

Nerium oleander is a fast-growing, tough, versatile evergreen shrub of great ornamental interest, largely utilized in urban environments (Pagen 1988) for its tolerance to drought (Bjorkman et al. 1980) and pollution (Dongarrà et al. 2003). Moreover, oleander is an easy-propagation plant and there is a large availability of genotypes with different flower colours in the local nurseries.

Tamarix genus is a group of plants naturalized extensively in dry and saline habitats in many countries (Brock 1994; González et al. 2010). The tamarisks are widely distributed in different natural habitats such as dunes, inland hilly districts, gravelly banks of rivers in all the Sicilian territory (Raimondo et al. 1982). Floristic data on the presence of $T$. gallica and $T$. canariensis L. from different localities of eastern Sicily and $T$. africana from the isles of Salina, Lipari and Vulcano (Aeolian Archipelago) and on the Etna volcano was provided by many Sicilian naturalists (Venturella et al. 2007). Tamarix gallica is the most widespread species occupying coastal dunes and the riverbanks of southern regions in Italy tolerating many abiotic stresses including salinity, drought, flooding, and extreme temperatures (Kuzminsky et al. 2014).

Finally, to avoid upsetting the original landscape based on palm trees as a dominant component, $W$. filifera was proposed, since among the palm species 
it seems to be one of the more resistant to the RPW attacks (Dembilio et al. 2009), probably also determined by the presence of a recently observed compound in the leaf tissues with larvicidal activity called filiferol (Cangelosi et al. 2015).

Before the actual data collection, we performed a pre-test, administering the questionnaire in a faceto-face manner to a few city council technicians and citizens. The need to indicate in the third part of the questionnaire a fourth species to be eventually specified by the respondent (as an open answer) in alternative to the three initially provided emerged from the results. The questionnaire was also completed with a brief description, including photos, of each species. The use of visual information in surveys (e.g., pictures of plant types), has a positive influence on people's understanding of the subject at hand (Asciuto et al. 2004b; Van Herzele et al. 2005).

The face-to-face interview survey involved a sample of 100 residents of over 15 years of age form Sant'Agata di Militello, who had agreed to collaborate in the research.

The size of the sample was determined with the formula of the simple casual sampling, considering a maximum estimation error of $10 \%$ and, in particular,

$$
n=\frac{p(1-\hat{p})\left(z_{\frac{\alpha}{2}}\right)^{2}}{d^{2}}=\frac{0.50 *(1-0.50) * 1.96^{2}}{0.010^{2}}=96
$$

where $p$ is the maximum population variance that is assumed to be equal to $0.5, \alpha$ represents the $5 \%$ significance level and $d$ is the maximum estimation error, and ${ }_{\frac{\alpha}{2}}$ is the critical value for a significance level of $5 \%(\alpha=5 \%)$. The sample size formula suggested setting the number of interviewees at more than 96 units.

\subsection{Sample description}

Table 1 gives the complete demographics of the sample. Our sample is formed by $50 \%$ males and $50 \%$ females, individuals mainly between 15 and 24 years of age (36\%), prevalently with a high school education (46\%) and students (28\%). The extracted sample is a convenience sample (non- probabilistic sample) as it has been composed with the first 100 people who agreed to take part in the interview. In this specific case, people over 55 years of age showed very little willingness to collaborate. Therefore, the sample is faithful to the official data from the $15^{\text {th }}$ Population Census (Istat, 2011) about the resident population in Sant'Agata di Militello in terms of sex distribution but slightly different in terms of distribution according to age classes and, consequently, also in the distribution of education and occupation.

Table 1: Socio-demographic characteristics of the sample ( $n=100)$

\begin{tabular}{|c|c|c|}
\hline \multirow{2}{*}{ Gender } & Males & $50 \%$ \\
\hline & Females & $50 \%$ \\
\hline \multirow{7}{*}{$\begin{array}{ll}\text { Age } & \text { (in } \\
\text { years) }\end{array}$} & $15-24$ & $36 \%$ \\
\hline & $25-34$ & $21 \%$ \\
\hline & $35-44$ & $12 \%$ \\
\hline & $45-54$ & $14 \%$ \\
\hline & $55-64$ & $8 \%$ \\
\hline & $65-74$ & $6 \%$ \\
\hline & $75-80$ & $3 \%$ \\
\hline \multirow{4}{*}{ Education } & Primary school & $4 \%$ \\
\hline & Lower secondary school & $29 \%$ \\
\hline & Upper secondary school & $46 \%$ \\
\hline & University degree & $21 \%$ \\
\hline \multirow{7}{*}{ Occupation } & Unemployed & $18 \%$ \\
\hline & Employed & $25 \%$ \\
\hline & Students & $28 \%$ \\
\hline & Freelance professionals & $10 \%$ \\
\hline & Retailers & $5 \%$ \\
\hline & Self-employed & $6 \%$ \\
\hline & Retired & $8 \%$ \\
\hline
\end{tabular}


Are you interested in the problems of green public areas, especially in the municipality of Sant' Agata di Miltello?

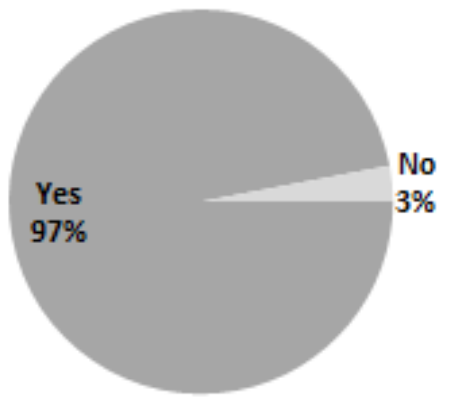

Do you usually goto the green areas of Sant'Agata di Miltello?
Are you happy with the management and maintenance o the public green areas of Sant'Aga' di Militello?
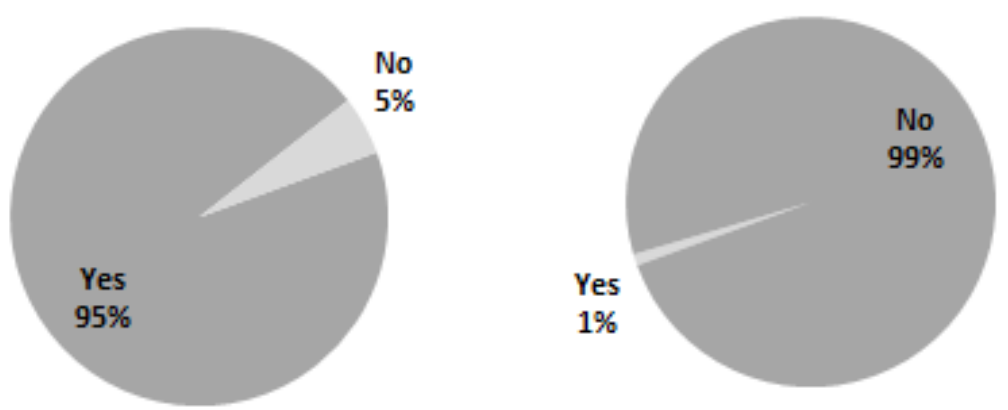

Figure 2: Degree of interest, fruition and satisfaction of the sample

\subsection{Results}

The great majority (97\%) of the sample declared to have an interest in the city council's urban green areas (Figure 2). As to the actual fruition of the green areas of the town, 95\% answered positively. Finally, $99 \%$ of the sample declared to be unsatisfied with the management and maintenance of the green public areas, which confirms the critical management and financial situations to be found in the municipalities, which are fairly common problems to the whole region.
As for the choice of the species to substitute the $P$. canariensis, $46 \%$ of the sample indicated a preference for $N$. oleander, $27 \%$ indicated $W$. filifera, while $26 \%$ chose $T$. gallica. Only one respondent was not satisfied with the provided species and indicated a different one, i.e. Cupressus sempervirens L. (Figure $3)$; this last one was indicated by the male subsample, which in general had shown a lower preference for $N$. oleander $(40 \%)$ and a higher one for $W$. filifera (30\%) and T. gallica (28\%) in comparison with the whole sample.

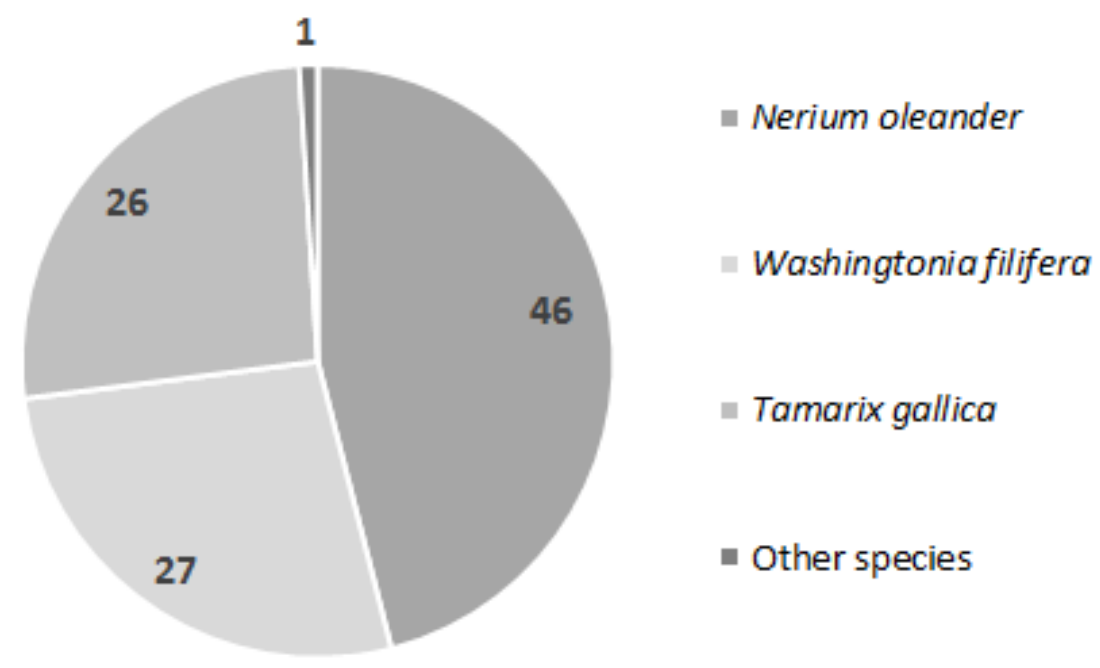

Figure 3: Species indicated by the sample for the substitution of the destroyed specimens of Phoenix canariensis 


\section{Discussion}

nvasive phytophagous species, which threaten ecosystems, habitat, or indigenous species, are an important element of global change and are contributing to biodiversity loss, ecosystem degradation, impairment of ecosystem services and landscape modification worldwide (Hulme 2009). Over recent decades, an increasing number of biological invasions have occurred worldwide, facilitated by climate change and trade market, causing economic impacts that can be valued as financial costs, based on expert extrapolations of high-profile alien pests (Pimentel et al. 2001; Born et al. 2005; Pimentel et al. 2005; Olson 2006). Moreover, alien insect invasions have subtle socioeconomic consequences, which are difficult to assess using traditional monetary approaches and market-based models (Binimelis et al. 2007). In many cases alien insect species attack ornamental plants that have become part of the landscape of urban environments, parks and gardens causing these to change (Pantaleoni et al. 2012).

Over the last years, the devastating impact of the introduction of the RPW in the landscapes of several Sicilian cities has been widely documented (Longo, Tamburino 2005; Peri et al. 2013). Palm trees have had a strong influence in the urban architecture and landscapes of many important cities of the Mediterranean basin (Manachini et al. 2013), and the urban landscape of many coastal areas of Italy is principally based on palms, many of which represent a patrimony of high value (Jucker, Lupi 2011). The RPW invasion has brought about a drastic decrease in the number of palms and a consequent radical change in urban spaces that may yet continue to transform the urban landscape. This landscape alteration poses in danger the place-identity itself defined by Lynch (1961) as 'the extent to which a person can recognize or recall a place as being distinct from otherplaces.' Moreover, it is not to exclude that the settlement of this weevil not only represents a serious environmental problem but will also have significant consequences on tourism (Jucker, Lupi 2011).
Normally, landscape pests do not need to be managed constantly, as their damage in general decreases through time (Weissling, Broschat 1999). By contrast, the RPW is lethal to palms and has required strong control measures such as quarantine and eradication to limit the widespread of this pest. Several attempts, such as chemical treatments, monitoring and mass trapping with pheromonekairomone traps and eradication of killed palms have been made to limit the destructive activity of the weevil from the beginning of its introduction (Abbas et al. 2001; Guarino et al. 2011, 2013, 2015; Vacas et al. 2013; Dembilio et al. 2014; Peri et al. 2017). However, the concealed nature of this pest and the fact that the infested palms are often located in urban areas where chemical treatments are not viable determined the fact that the RPW continued to expand and spread to other areas.

Consequently, doubts have been raised about the opportunity to continue to put efforts in RPW control measures. The basic parameter to be considered is cost-effectiveness: i.e., does the value of the plant needing protection always justify the costs of the protective measures?

The establishment of the RPW determined evident changes in the ecosystem of the island (Sicily), so the strategy to replace the killed palms with other ornamental plants could be an economically sustainable solution rather than continue fighting a losing battle.

On the other hand, it is important to directly involve the people that live and exploit the green areas of the regions affected by the RPW on decisions concerning residential landscape management. Our findings show that citizens have a great interest in green areas and a positive attitude towards urban green spaces, indicating a willingness to contribute in the planning and the management of green spaces. These findings are in accordance with similar results of studies conducted in several other countries (Balram, Dragićević 2005; Jim, Chen 2006; Sanesi, Chiarello 2006; Janse, Konijnendijk 2007; Greene et al. 2011; Lee, Kim 2015; Ostoić et al. 2017). 


\section{Conclusions}

A clear understanding of the citizens' needs about green areas can improve the management of public parks as well as the effective implementation of protection and preservation programs or rehabilitation projects of urban green spaces, all of which are important to provide the experience of nature and to contribute to urban biodiversity and living quality.

Thenceforth it is reasonable to involve citizens on the natural resource management using public participation processes that are normally designed to enhance communication and consultation through methods such as public information, public hearings, conferences, and formation of advisory groups (Janse, Konijnendijk 2007).

In the case study reported, the involvement of the citizens of Sant'Agata di Militello in the choice of tree species suitable for the replacement of $P$. canariensis specimens destroyed by the RPW was a useful exercise of collective responsibility in the planning decisions of urban green areas, which should be extended to other municipalities affected by the problem of the RPW and to all aspects of the management and care of the urban green more generally. This is suitable for the preparation of further and more in-depth surveys within a work path allowing to explore the citizens' needs and opinions about urban green areas planning when these ecosystems are threatened by biotic or abiotic factors. The involvement of the population in decisions on urban green planning can lead to a correct destination of public funds to improve the use and enjoinment of the public green areas. Furthermore, the multidisciplinary aspect of this research highlighted the importance of the involvement of different scientific knowledge in the management of urban green issues.

\section{References}

Abbas, M.S.T.; Saleh, M.M.E. \& Akil, A.M. 2001. Laboratory and field evaluation of the pathogenicity of entomopathogenic nematodes to the Red Palm Weevil, Rhynchophorus ferrugineus (Oliv.) (Col.: Curculionidae). Anzeiger für Schädlingskunde, 74: 167-168.

Asciuto, A.; Borsellino, V.; D’Acquisto, M.; Di Franco, C.P.; Di Gesaro, M. \& Schimmenti, E. 2015. Monumental trees and their existence value: case study of an Italian natural park. Journal of Forest Science, 61: 55-61.

Asciuto, A.; Fiandaca, F. \& Schimmenti, E. 2004a. Stima della disponibilità a pagare per la salvaguardia di un'area protetta siciliana da gli incendi boschivi [Estimation of willingness to pay for the defence from forest fires of a protected area of Sicily]. Aestimum, Firenze University Press, Firenze, 45: 1-29.

Asciuto, A.; Fiandaca, F. \& Schimmenti, E. 2004b. Un'applicazione del metodo delle preferenze visive per la valutazione non-monetaria del paesaggio forestale in un'area del Parco delle Madonie [An application of the method of visual preferences for non-monetary evaluation of the forest landscape in an area of the Madonie]. Collana Sicilia Foreste, 24, Supplemento alla rivista trimestrale Sicilia Foreste, pp 115, Industria Grafica T. Sarcuto, Agrigento, Italy.

Bacon, S.J.; Bacher, S. \& Aebi, A. 2012. Gaps in Border Controls Are Related to Quarantine Alien Insect Invasions in Europe. Plos One 7(10): e47689. https://doi.org/10.1371/journal.pone.0047689

Balram, S. \& Dragićević, S. 2005. Attitudes toward urban green spaces: integrating questionnaire survey and collaborative GIS techniques to improve attitude measurements. Landscape and Urban Planning, 71(2): 147-162. 
Barbera, G. \& Romano, D. 2009. Le palme nel paesaggio Siciliano [Palms in the Sicilian landscape]. Regione Sicilia, Assessorato Agricoltura e Foreste - Dipartimento Interventi Infrastrutturali, La Ricerca Scientifica sul punteruolo rosso e gli altri fitofagi delle palme in Sicilia, Centro Stampa Rubino, Marsala, 1: 29-38.

Binimelis, R.; Born, W.; Monterroso, I. \& RodríguezLabajos, B. 2007. Socio-economic impact and assessment of biological invasions. Biological invasions, Springer Berlin Heidelberg, 193: 331347.

Bjorkman, O.; Downton, W.J.S. \& Mooney, H.A. 1980. Response and adaptation to water stress in Nerium oleander. Dept of Plant Biology (USA), Annual Report-Carnegie Institution of Washington.

Bolund, P. \& Hunhammar S. 1999. Ecosystem services in urban areas. Ecological Economics, 29: 293-301.

Born, W.; Rauschmayer, F. \& Bräuer, I. 2005. Economic evaluation of biological invasions - a survey. Ecological Economics, 55: 321-336.

Brock, J.H. 1994. Tamarix spp. (salt cedar), an invasive exotic woody plant in arid and semi-arid riparian habitats of western USA. Ecology and Management of Invasive Riverside Plants, 27-44.

Buchel, S. \& Frantzeskaki, N. 2015. Citizens' voice: A case study about perceived ecosystem services by urban park users in Rotterdam, the Netherlands. Ecosystem Services, 12: 169-177.

Cangelosi, B.; Clematis, F.; Monroy, F.; Roversi, P.F.; Troiano, R.; Curir, P. \& Lanzotti, V. 2015. Filiferol, a chalconoid analogue from Washingtonia filifera possibly involved in the defence against the Red Palm Weevil Rhynchophorus ferrugineus Olivier. Phytochemistry, 115: 216-221.
Chan, K.M.A.; Satterfield, T. \& Goldstein, J. 2012. Rethinking ecosystem services to better address and navigate cultural values. Ecological Economics 74,8-18.

Chiesura, A. 2004. The role of urban parks for the sustainable city. Landscape and Urban planning, 68: 129-138.

Dembilio, Ó.; Jacas, J.A. \& Llácer, E. 2009. Are the palms Washingtonia filifera and Chamaerops humilis suitable hosts for the Red Palm Weevil, Rhynchophorus ferrugineus (Col. Curculionidae)? Journal of Applied Entomology, 133: 565-567.

Dembilio, Ó.; Riba, J.M.; Gamón, M. \& Jacas, J.A. 2014. Mobility and efficacy of abamectin and imidacloprid against Rhynchophorus ferrugineus in Phoenix canariensis by different application methods. Pest Management Science, 71: 10911098.

Dempsey, N. \& Burton, M. 2012. Defining placekeeping: the long-term management of public spaces. Urban For. Urban Green. 11: 11-20.

Dongarrà, G.; Sabatino, G.; Triscari, M. \& Varrica, D. 2003. The effects of anthropogenic particulate emissions on roadway dust and Nerium oleander leaves in Messina (Sicily, Italy). Journal of Environmental Monitoring, 5: 766-773.

Eigenbrode, S.D.; O'rourke, M.; Wulfhorst, J.D.; Althoff, D.M.; Goldberg, C.S.; Merrill, K.; Morse W.; Nielsen-Pincus M.; Stephens J.; Winowieki L. \& Bosque-Pérez, N.A. 2007. Employing philosophical dialogue in collaborative science. BioScience, 57(1): 55-64.

European Commission, Directorate-General For Health and Food Safety 2011. The insect killing our palm trees. EU efforts to stop the Red Palm Weevil. 
Faleiro, J.R. 2006. A review of the issues and management of the Red Palm Weevil Rhynchophorus ferrugineus (Coleoptera: Rhynchophoridae) in coconut and date palm during the last one hundred years. International Journal of Tropical Insect Science, 26: 135-154.

Ferry, M. \& Gomez, S. 2002. The Red Palm Weevil in the Mediterranean area. Palms-Lawrence, 46: 172-178.

Freestone, R. \& Nichols, D. 2004. Realising new leisure opportunities for old urban parks: the internal reserve in Australia. Landscape and Urban Planning, 68: 109-120.

Frischenbruder, M.T.M. \& Pellegrino, P. 2006. Using greenways to reclaim nature in Brazilian cities. Landscape and Urban Planning 76: 67-78.

Giannetto, C.; Dragulanescu, I.V. \& Lanfranchi, M. 2016. Urban agriculture as a tool for a sustainable development of the city of Messina. Quality Access to Success, 17(S1): 236-241.

Gilbert, M.; Guichard, S.; Freise, J.; Grégoire, J.-C.; Heitland, W.; Straw, N.; Tilbury, C. \& Augustin, S. 2005. Forecasting Cameraria ohridella invasion dynamics in recently invaded countries: from validation to prediction. Journal of Applied Ecology, 42: 805-813.

Giovino, A.; Agnello, S.; Salamone, A. \& Zizzo, G.V. 2009. Importanza economica delle palme in Sicilia e riflessi commerciali dopol'introduzione del Punteruolo rosso [Economic importance of Palms in Sicily and trade changes after the introduction of the Red Palm Weevil]. Regione Sicilia, Assessorato Agricoltura e Foreste - Dipartimento Interventi Infrastrutturali, La Ricerca Scientifica sul punteruolo rosso e gli altri fitofagi delle palme in Sicilia, Centro Stampa Rubino, Marsala, 1: 3942.
Goddard, M.A.; Dougill, A.J. \& Benton, T.G. 2010. Scaling up from gardens: biodiversity conservation in urban environments. Trends in Ecology \& Evolution, 25: 90-98.

Gomez-Baggethun, E. \& Barton, D.N. 2013. Classifying and valuing ecosystem services for urban planning. Ecological Economics 86: 235245.

González, E.; González-Sanchis, M.; Cabezas, Á.; Comín, F.A. \& Muller, E. 2010. Recent changes in the riparian forest of a large regulated Mediterranean river: implications for management. Environmental Management, 45: 669-681.

Greene, C.S.; Millward, A.A. \& Ceh, B. 2011. Who is likely to plant a tree? The use of public socio-demographic data to characterize client participants in a private urban forestation program. Urban Forestry \& Urban Greening, 10(1): 29-38.

Guarino, S.; Colazza, S.; Peri, E.; Lo Bue, P.; Germanà, M.P.; Kuznetsova, T.; Gindin G. \&Soroker, V. 2015. Behaviour-modifying compounds for management of the Red Palm Weevil (Rhynchophorus ferrugineus Oliver). Pest Management science 71: 1605-1610.

Guarino, S.; Lo Bue, P.; Peri, E. \& Colazza, S. 2011. Responses of Rhynchophorus ferrugineus adults to selected synthetic palm esters: electroantennographic studies and trap catches in an urban environment. Pest Management Science, 67: 77-81.

Guarino, S.; Peri, E.; Lo Bue, P.; Germanà, M.P.; Colazza, S.; Anshelevich, L.; Ravid, U. \& Soroker, V. 2013. Assessment of synthetic chemicals for disruption of Rhynchophorus ferrugineus response to attractant-baited traps in an urban environment. Phytoparasitica, 41: 79-88. 
Hulme, P.E. 2009. Trade, transport and trouble: managing invasive species pathways in an era of globalization. Journal of Applied Ecology, 46: 1018.

Islam, M.N.; Rahman, K. S.; Bahar, M.M.; Habib, M.A.; Ando, K.; Hattori, N. 2012. Pollution attenuation by roadside greenbelt in and around urban areas. Urban Forestry \& Urban Greening, 11: 460-464.

Istat 2011. $5^{\text {th }}$ Population and housing census. http:// dati-censimentopopolazione.istat.it/Index.asp $\mathrm{x}$ ?lang=en\&SubSessionld=f4f92ad8-0dfe-42aa8601-4ae1ee4c3c17\&themetreeid=-200 (Date: 09.05.2017)

Janse, G. \& Konijnendijk, C.C. 2007. Communication between science, policy and citizens in public participation in urban forestry. Experiences from the Neighbourwoods project. Urban Forestry \& Urban Greening, 6(1): 23-40.

Jim, C.Y. \& Chen, W.Y. 2006. Perception and attitude of residents toward urban green spaces in Guangzhou (China). Environmental management, 38(3): 338-349.

Jim, C.Y. \& Chen, W.Y. 2009. Urbanization effect on floristic and landscape patterns of green spaces. Landscape Research, 34: 581-598.

Jucker, C. \& Lupi, D. 2011. Exotic Insects in Italy: An overview on their environmental impact. In Lopez-Pujol, J. (Ed.), The Importance of Biological Interactions in the Study of Biodiversity. InTech, 51-74. doi: 10.5772/24263.

Kenis, M.; Auger-Rozenberg, M.A.; Roques, A.; Timms, L.; Péré, C.; Cock, M.J.W.; Settele, J.; Augustin, S. \& Lopez-Waamonde, C. 2009. Ecological effects of invasive alien insects. In Langor D.W., Sweeney J. (Eds.), Ecological Impacts of Non-Native Invertebrates and Fungi on Terrestrial Ecosystems. Berlin, Springer: $21-45$.
Khera, N.; Mehta, V. \& Sabata, B.C. 2009. Interrelationship of birds and habitat features in urban greenspaces in Delhi, India. Urban Forestry \& Urban Greening, 8: 187-196.

Konijnendijk, C.C. 2000. Adapting forestry to urban demands. Role of communication in urban forestry in Europe. Landscape and Urban Planning, 52(2): 89-100.

Kontodimas, D.C.; Milonas, P.; Vassiliou, V.; Thymakis, N. \& Economou, D. 2006. The occurrence of Rhynchophorus ferrugineus in Greece and Cyprus and the risk against the native Greek palm tree Phoenix theophrasti. Entomologia Hellenica, 16: 11-15.

Kühn, M. 2003. Greenbelt and Green Heart: separating and integrating landscapes in European city regions. Landscape and Urban Planning, 64(1): 19-27.

Kuzminsky, E.; De Angelis, P.; Jaoudé, R.A.; Abbruzzese, G.; Terzoli, S.; Angelaccio, C.; De Dato, G.; Monteverdi, M.C. \& Valentini, R. 2014. Biodiversity of Italian Tamarix spp. populations: their potential as environmental and productive resources. Rendiconti Lincei, 25: 439-452.

Lanfranchi, M.; Giannetto, C.; De Pascale, A. \& Hornoiu, R.I. 2015. An application of Qualitative Risk Analysis as a tool adopted by public organizations for evaluating "Green projects". Amfiteatru Economic, 17(40): 872-890.

Lawrence, A.; De Vreese, R.; Johnston, M.; van den Bosch, C.C.K. \& Sanesi, G. 2013. Urban forest governance: towards a framework for comparing approaches. Urban Forestry \& Urban Greening, 12(4): 464-473.

Lee, Y.C. \& Kim, K.H. 2015. Attitudes of citizens towards urban parks and green spaces for urban sustainability: The case of Gyeongsan city, Republic of Korea. Sustainability, 7(7): 8240-8254. 
Longo, S. \& Tamburino, V. 2005. Gravi infestazioni di punteruolo rosso della palma [Severe infestations of Red Palm Weevil]. Informatore Agrario, 50: 7374.

Longo, S.; Anderson, P.J.; Smith, T. \& Stanley Inserra, R. 2011. New Palm Hosts for the Red Palm Weevil, Rhynchophorus ferrugineus, in Sicily. Palms, 55: 15-20.

Lorenzo, A.B.; Blanche, C.A.; Qi, Y. \& Guidry, M.M. 2000. Assessing residents' willingness to pay to preserve the community urban forest: a smallcity case study. Journal of Arboriculture, 26: 319325.

Lynch K. 1961. A Theory of Good City Form, Cambridge MA.

Manachini, B.; Billeci, N. \& Palla, F. 2013. Exotic insect pests: The impact of the Red Palm Weevil on natural and cultural heritage in Palermo (Italy). Journal of Cultural Heritage, 14(3): 177-182.

Marone, E. \& Riccioli, F. 2008. Manuale RISVEM linee guida tecnico-operative per la pianificazione, progettazione realizzazione gestione di spazi verdi multifunzionali [RISVEM manual, technical and operational guidelines for the planning, design, implementation, management of multifunctional green spaces], Firenze, 233-255.

Martín-López, B.; Iniesta-Arandia, I.; García-Llorente, M.; Palomo, I.; Casado-Arzuaga, I.; García Del Amo, D.; Gómez-Baggethun, E.; Oteros-Rozas, E.; Palacios-Agundez, I.; Willaarts, B.; González, J.A.; Santos-Martín, F.; Onaindia, M.; López-Santiago, C. \& Montes, C. 2012. Uncovering ecosystem service bundles through social preferences. PLoSOne 7(6), https://doi.org/10.1371/journal. pone.0038970.
Nardi, S.; Ricci, E.; Lozzi, R.; Marozzi, F.; Ladurner, E.; Chiabrando Granchelli, F.L.; Verdolini, E.; Isidoro, N. \& Riolo, P. 2011. Control of Rhynchophorus ferrugineus (Olivier, 1790) according to EU Decision 2007/365/EC in the Marche region (Central Eastern Italy). EPPO Bulletin, 41: 103-115.

Noto, G. \& Romano, D. 1987. Palms in the urban environment in the southern latitudes of Italy. ActaHorticulturae, 195: 91-97.

Olson, L.J. 2006. The economics of terrestrial invasive species: a review of the literature. Agricultural and Resource Economics Review, 35: 178-194.

Ostoić, S.K.; van den Bosch, C.C.K.; Vuletić, D.; Stevanov, M.; Živojinović, I.; Mutabdžija-Bećirović, S.; Lazarević, J.; Stojanova, B.; Blagojević, D.; Stojanovska, M.; Nevenić, R. \& Malovrh, S.P. (2017). Citizens' perception of and satisfaction with urban forests and green space: Results from selected Southeast European cities. Urban Forestry \& Urban Greening, 23: 93-103.

Pagen, F.J.J. 1988. Series of revisions of Apocynaceae XX. Oleanders: Nerium L. and the oleander cultivars. Agricultural University Wageningen Pap, 87: 1-113.

Palmer, M.A.; Bernhardt, E.S.; Chornesky, E.A.; Collins, S.L.; Dobson, A.P.; Duke, C.S.; Gold, B. D.; Jacobson, R.; Kingsland, S.E.; Kranmz, R.H.; Mappin, M.J.; Martinez, L.; Micheli, F.; Morse, J.; Pace, M.L.; Pascual, M.; Palumbi, S.S.; Reichman, O.; Townsed, A.R. \& Turner M. 2005. Ecological science and sustainability for the 21st century. Frontiers in Ecology and the Environment, 3(1): 4-11.

Pantaleoni, R.A.; Cesaroni, C.; Cossu, S.; Deliperi, S.; Fadda, L.; Fois, X.; Lentini, A.; Loi, A.; Loru, L.; Molinu, A.; Nuvoli, M.T.; Ramassini, W.; Sassu, A.; Serra, G. \& Verdinelli, M. 2012. Impact of alien insect pests on Sardinian landscape and culture. Biodiversity Journal, 3: 297-310. 
Pasini, C. \& Rumine, P. 2014. II Punteru olo rosso delle palme Rhynchophorus ferrugineus (Olivier): biologia, dannosità e linee di difesa [The Red Palm Weevil Rhynchophorus ferrugineus (Olivier): biology, harmfulness and defense lines]. Italus Hortus, 21: 49-65.

Pavone, P. \& Salmeri, C. 1994. II verde pubblico di Catania: villa Bellini [Villa Bellini in Catania urbancontext]. Bollettino Accademia Gioenia Scienze Naturali 27: 163-195.

Pellizzari, G.; Dalla Montà, L. \& Vacante, V. 2005. Alien insect and mite pests introduced to Italy in sixty years (1945-2004). In Plant Protection and Plant Health in Europe: Introduction and Spread of Invasive Species. BCPC Symposium Proceedings, Vol. 81, p. 275. BCPC, U.K.

Peri, E.; Colazza, S.; Guarino, S.; Suma, P.; La Pergola, A. \& Longo, S. 2013. The Red Palm Weevil in Sicily: the introduction and spread of an invasive alien species. In Colloque méditerranéen sur les ravageurs des palmiers, Nice, France, 16-18 Janvier 2013, Association Française de Protection des Plantes (AFPP), 171-177.

Peri, E.; Rochat, D.; Belušic, G.; Ilic, M. ; Soroker, V.; Barkan, S.; Guarino S.; Lo Bue P. \& Colazza, S. 2017. Rhynchophorus ferrugineus: Behavior, Ecology, and Communication. In: Soroker, V., Colazza, S. (Eds.), Handbook of Major Palm Pests: Biology and Management. Wiley-Blackwell, U.K.

Pimentel, D.; Mcnair S.; Janecka, J.; Wightman, J.; Simmonds, C.; O'Connell, C.; Wong, E.; Zern, J.; Aquino, T. \& Tsomondo, T. 2001. Economic and environmental threats of alien plant, animal, and microbe invasions. Agriculture, Ecosystems \& Environment, 84: 1-20.

Pimentel, D.; Zuniga, R. \& Morrison, D. 2005. Update on the environmental and economic costs associated with alien-invasive species in the United States. Ecological Economics, 52: 273-288.
Raciti, E.; Conti, F.; Carta Cerrella, D.; Morabito, M.; Li Destri, A.; Malfitana, S. \& Romano, D. 2013. Palm species potentially resistant to Red Palm Weevil attacks in sites of eastern Sicily heavily infested. In Colloque méditerranéen sur les ravageurs des palmiers, Nice, France, 16-18 Janvier 2013, Association Française de Protection des Plantes (AFPP).

Raimondo, F. M.; Rossitto, M. \& Villari, M. 1982. Bibliografia geobotanica siciliana. Programma finalizzato "Promozione della qualità dell'ambiente" C.N.R. Aq/1/236.

Raupp, M.J.; Shrewsbury, P.M. \& Herns, D.A. 2010. Ecology of herbivorous arthropods in urban landscapes. Annual Review of Entomology, 55: 19-38.

Roques, A.; Rabitsch, W.; Rasplus, J.Y.; LopezVaamonde, C.; Nentwig, W. \& Kenis, M. 2009. Alien Terrestrial Invertebrates of Europe. In Handbook of Alien Species in Europe. Springer Series in Invasion Ecology, 3:63-79.

Roseland, M. 1998. Toward Sustainable Communities: Resources for Citizens and Their Governments. New Society Publishers, Gabriola Island, BC.

Salmeri, C.; Guglielmo, A. \& Pavone, P. 2007. II giardino di villa "La Falconara" a Taormina (Sicilia orientale) ["La Falconara" Garden in Taormina, Eastern Sicily)]. Quaderni botanica ambientale applicata, 18: 93-98.

Sanesi, G. \& Chiarello, F. 2006. Residents and urban green spaces: the case of Bari. Urban Forestry \& Urban Greening, 4(3): 125-134.

Simonsen, W. \& Robbins, M.D. 2000. Citizen Participation in Resource Allocation. Westview Press, Boulder, CO. 
Susca, T.; Gaffin, S. R. \& Dell'Osso, G. R. 2011. Positive effects of vegetation: Urban heat island and green roofs. Environmental Pollution, 159 (8): 2119-2126.

Takebayashi, H. \& Moriyama, M., 2007. Surface heat budget on green roof and high reflection roof for mitigation of urban heat island. Building and Environment, 42 (8): 2971-2979.

Trakolis, D. 2001. Local people's perceptions of planning and management issues in Prespes Lakes National Park, Greece. Journal of Environmental Management, 61(3): 227-241.

Vacas, S.; Primo, J. \& Navarro-Llopis, V. 2013. Advances in the use of trapping systems for Rhynchophorus ferrugineus (Coleoptera: Curculionidae): traps and attractants. Journal of Economic Entomology, 106: 1739-1746.

Van Herzele, A.; Collins, K. \& Tyrvainen, L. 2005. Involving people in urban forestry - a discussion of participatory practices throughout Europe. In: Konijnendijk, C. C., Nilsson, K., Randrup, T.B., Schipperijn, J. (Eds.), Urban Forests and Trees. Springer, Berlin, Heidelberg, New York, pp. 207228 (Chapter 8).

Venturella, G.; Baum, B. \& Mandracchia, G. 2007. The genus Tamarix (Tamaricaceae) in Sicily: first contribution. Flora mediterranea, 17: 25-46.

Weissling, T.J. \& Broschat, T.K. 1999. Integrated management of palm pests. In ProceedingsFlorida State Horticultural Society, 112: 247-250. 